\title{
Oxygen Extraction in Lamb Skeletal Muscle
}

\author{
MARC B. HERSHENSON, P. PEARL O'ROURKE, DIMITRI A. CHRISTAKIS, \\ BARBARA J. COOPES, AND ROBERT K. CRONE \\ Departments of Anaesthesia and Pediatrics, Harvard Medical School, The Children's Hospital, \\ Boston, Massachusetts 02115
}

\begin{abstract}
Past studies have found that total-body $\mathrm{O}_{2}$ extraction during hypoxia was less in 1-wk-old lambs than in older animals. It was proposed that reduced $\mathrm{O}_{2}$ extraction was secondary to suppression of growth-related oxygen consumption $\left(\dot{V}_{\mathrm{O}_{2}}\right)$ in tissues such as skeletal muscle, bone, kidney, and skin, rather than a defect in peripheral $\mathrm{O}_{2}$ use. To determine the capacity of immature skeletal muscle to extract $\mathrm{O}_{2}$, we isolated the hind limb circulation of eight ketamine-anesthetized, 7- to 18-d-old lambs exposed to stagnant hypoxia by inflation of a right atrial balloon catheter. Femoral arterial and venous $\mathrm{PO}_{2}, \mathrm{PCO}_{2}, \mathrm{pH}, \mathrm{Hb}$ concentration, $\mathrm{O}_{2}$ saturation, and femoral arterial blood flow $(\mathrm{Q})$ were measured and hind limb $\mathrm{O}_{2}$ delivery $\left(\mathrm{DO}_{2}\right)$, extraction ratio, and $\dot{\mathrm{V}}_{2}$ calculated. Individual critical levels of $\mathrm{DO}_{2}$ below which $\mathrm{VO}_{2}$ was dependent on $\mathrm{O}_{2}$ supply were determined by dual-line best-fit regression analysis. In six of eight animals, $\dot{\mathrm{V}}_{2}$ was clearly independent of supply until $\mathrm{DO}_{2}$ reached critically low levels. However, $\mathrm{O}_{2}$ extraction during extreme hypoxia appeared submaximal (baseline $\mathrm{O}_{2}$ extraction ratio, $0.22 \pm 0.06$; at critical levels of $\mathrm{DO}_{2}, 0.51 \pm 0.11$; at the lowest level of $\mathrm{Q}, 0.64 \pm$ 0.15 ). When 2,4-dinitrophenol, an uncoupler of oxidative phosphorylation, was administered to four additional lambs exposed to stagnant hypoxia, $\mathrm{O}_{2}$ extraction below critical levels of $\mathrm{DO}_{2}$ increased from $0.48 \pm 0.15$ to $0.79 \pm 0.10$ ( $p<0.001$, unpaired $t$ test). These data suggest that initial limitations in $\mathrm{O}_{2}$ extraction were a result of the suspension of $\mathrm{O}_{2}$-consuming processes, not an irreversible defect in peripheral $\mathrm{O}_{2}$ use. (Pediatr Res 28: 101-105, 1990)
\end{abstract}

\section{Abbreviations}

DNP, 2,4-dinitrophenol

$\mathrm{DO}_{2}, \mathrm{O}_{2}$ delivery

$\mathrm{DO}_{2}$ crit, critical level of $\mathrm{DO}_{2}$

Q, blood flow

$\dot{\mathrm{V}}_{2}, \mathrm{O}_{2}$ consumption

$\mathrm{P}_{50}, \mathrm{PO}_{2}$ at which $\mathrm{Hb}$ was $50 \%$ saturated

ANOVA, analysis of variance

[Hb], Hb concentration

$\mathrm{pH}_{\mathrm{a}}$, arterial $\mathrm{pH}$

Sidi et al. (1) found that total-body $\mathrm{O}_{2}$ extraction during extreme hypoxic hypoxia was significantly less in 1-wk-old lambs than in older (3-7 wk) animals. Because of the lack of acidosis with hypoxia and minimal increase in $\dot{\mathrm{V}}_{2}$ on recovery, they proposed that reduced $\mathrm{O}_{2}$ extraction was secondary to a suppression of growth-related $\mathrm{V}_{2}$ in tissues such as muscle, bone,

Received August 29, 1989; accepted April 12, 1990.

Correspondence: Marc B. Hershenson, M.D., University of Chicago, Wyler Children's Hospital, 5841 S. Maryland Avenue, Box 307, Chicago, IL 60637.

Supported by the CHMC Anesthesia Foundation and National Research Service Award 1-T32-HL07633-03. kidney, and skin, rather than an impairment in peripheral tissue extraction. To test the hypothesis that immature skeletal muscle $\mathrm{O}_{2}$ extraction is submaximal during extreme hypoxia, we isolated the hind limb circulation of eight anesthetized, 7- to 18-d-old lambs exposed to stagnant hypoxia.

If $\mathrm{O}_{2}$ extraction in lamb skeletal muscle is reduced secondary to the suppression of growth-related $\dot{\mathrm{V}}_{2}$, increments in $\mathrm{O}_{2}$ demand should increase $\mathrm{O}_{2}$ extraction. We therefore exposed four additional animals to both stagnant hypoxia and DNP, an uncoupler of oxidative phosphorylation.

\section{MATERIALS AND METHODS}

Animal preparation. Our study was approved by The Children's Hospital Committee on Animal Investigation. Twelve lambs, 7-18 d of age, wt 3.6-8.2 kg, were studied. Animals were housed in air-conditioned rooms at the Children's Hospital Animal Facility. Lambs were anesthetized with ketamine (5-10 mg/ $\mathrm{kg}$ i.v. bolus followed by a continuous infusion of $5-10 \mathrm{mg}$. $\left.\mathrm{kg}^{-1} \cdot \mathrm{h}^{-1}\right)$. The exact dosage used was chosen to abolish motor, heart rate, and pressor responses to stimulation. After a satisfactory level of anesthesia was obtained, pancuronium $(0.1 \mathrm{mg}$. $\mathrm{kg}^{-1} \cdot \mathrm{h}^{-1}$ i.v.) was given. Animals were endotracheally intubated and mechanically ventilated (Healthdyne, Marietta, GA) to keep arterial $\mathrm{CO}_{2}$ pressure at approximately $4 \mathrm{kPa}$. Arterial $\mathrm{O}_{2}$ pressure was maintained at or near $13 \mathrm{kPa}$. All animals were given 10 $\mathrm{mL} / \mathrm{kg}$ of normal saline i.v. and maintained on $3 \mathrm{~mL} \cdot \mathrm{kg}^{-1} \cdot \mathrm{h}^{-1}$ of a solution of $5 \%$ dextrose and normal saline for the remainder of the experiment. Temperature was maintained at $38^{\circ} \mathrm{C}$ using a temperature probe, water-blanket, and temperature control unit.

Hind limb arterial and venous $Q$ were then isolated to the main femoral artery and vein. The left femoral artery, nerve, and vein were dissected free, and nylon ties (Akcess Medical Products, New Brunswick, NJ) passed under the femoral sheath to achieve arterial and venous occlusion. To prevent thrombosis, heparin (1000 U/kg i.v.) was given just before tightening. Another tie was secured at the ankle to exclude any contribution from the paw. Isolation of the hind limb was confirmed after each experiment by injecting india ink into the femoral artery; only muscle distal to the nylon ties stained black. In addition, femoral arterial and venous flows (see below) were the same in each experiment.

Hind limb Q was measured continuously by a nonocclusive ultrasonic flow probe (Transonic Systems, Ithaca, NY) placed around the femoral artery. Arterial placement was preferred due to the small cross-sectional area of the femoral vein (generally $<2 \mathrm{~mm}^{2}$ ). Periodic measurement of femoral venous flow revealed no difference between femoral venous and arterial flow. A vigorous reactive hyperemia in response to arterial occlusion was seen throughout each experiment, except just before cardiovascular collapse. The flow probe was calibrated before each experiment with saline pumped at a known rate through cellulose membrane tubing (Spectrum Medical Industries, Los Angeles, CA). Next, a 3/4" 24-gauge catheter (Critikon, Tampa, FL) was placed in a superficial branch of the femoral vein. The lumen of the catheter ended at the junction of the branch and main 
Table 1. Baseline group mean data $(n=8 \text {, mean } \pm S D)^{*}$

$\begin{array}{lc}{[\mathrm{Hb}](\mathrm{g} / \mathrm{dL})} & 10.0 \pm 1.3 \\ \mathrm{PaO}_{2}(\mathrm{kPa}) & 13.7 \pm 1.4 \\ \mathrm{PvO}_{2}(\mathrm{kPa}) & 5.7 \pm 1.2 \\ \mathrm{PaCO}_{2}(\mathrm{kPa}) & 4.3 \pm 0.9 \\ \mathrm{P}_{50}(\mathrm{kPa}) & 3.9 \pm 0.5 \\ \mathrm{SaO}_{2}(\%) & 99 \pm 1 \\ \mathrm{SvO}_{2}(\%) & 77 \pm 7 \\ \mathrm{pH}_{\mathrm{a}} & 7.44 \pm 0.07 \\ \mathrm{pH} & 7.36 \pm 0.07 \\ \mathrm{Femoral} \text { artery Q }\left(\mathrm{mL} \cdot \mathrm{min}^{-1} \cdot 100 \mathrm{~g}^{-1}\right) & 11.30 \pm 3.80 \\ \mathrm{Hind} \mathrm{limb} \mathrm{DO} & \left(\mathrm{mL} \cdot \mathrm{min}^{-1} \cdot 100 \mathrm{~g}^{-1}\right) \\ \mathrm{Hind} \mathrm{limb} \mathrm{VO}_{2}\left(\mathrm{~mL} \cdot \mathrm{min}^{-1} \cdot 100 \mathrm{~g}^{-1}\right) & 1.57 \pm 0.60 \\ \mathrm{O}_{2} \text { ext } & 0.34 \pm 0.04 \\ \end{array}$

*Values are mean $\pm \mathrm{SD}$. $\mathrm{PaO}_{2}$, arterial $\mathrm{O}_{2}$ pressure; $\mathrm{PvO}_{2}$, venous $\mathrm{O}_{2}$ pressure: $\mathrm{PaCO}_{2}$, arterial $\mathrm{CO}_{2}$ pressure; $\mathrm{SaO}_{2}$, arterial saturation of $\mathrm{Hb}$ with $\mathrm{O}_{2} ; \mathrm{SvO}_{2}$, venous saturation of $\mathrm{Hb}$ with $\mathrm{O}_{2} ; \mathrm{pH}_{\mathrm{v}}$, venous $\mathrm{pH} ; \mathrm{O}_{2}$ ext, $\mathrm{O}_{2}$ extraction ratio.

femoral vein. In this way, femoral venous blood samples could be obtained without inducing venous obstruction. Arterial samples were collected and arterial pressure monitored via a catheter placed in the contralateral femoral artery. Finally, an 8 French Foley catheter was placed in the right atrium via the right jugular vein for reducing cardiac output in a controlled, stepwise fashion (2).

Experimental protocol. In experiment 1, the capacity of immature skeletal muscle to extract $\mathrm{O}_{2}$ was evaluated in eight lambs exposed to stagnant hypoxia. After a 1-h stabilization period, we made baseline measurements of femoral arterial and venous $\mathrm{O}_{2}$ and $\mathrm{CO}_{2}$ tensions, $\mathrm{pH},[\mathrm{Hb}], \mathrm{O}_{2}$ saturation, and femoral arterial Q. Blood gases were measured using a Corning (Medfield, MA) $168 \mathrm{pH} /$ blood gas analyzer. [Hb] and $\mathrm{O}_{2}$ saturation were measured using an Instrumentation Laboratories (Lexington, MA)
282 Co-Oximeter whose absorption wavelengths were adjusted to measure the [Hb] and $\mathrm{O}_{2}$ saturation of bovine blood. Next, the atrial balloon was inflated to produce an approximately $1-\mathrm{kPa}$ reduction in mean arterial pressure. Initially, small inflations of the balloon $(0.5-1 \mathrm{~mL})$ were sufficient to produce $1-\mathrm{kPa}$ reductions in arterial pressure. Thereafter, compensatory increases in blood pressure often occurred, requiring larger inflations (approximately $2 \mathrm{~mL}$ ). After $15 \mathrm{~min}$, measurements of femoral arterial and venous [ $\mathrm{Hb}], \mathrm{O}_{2}$ saturation, blood gases, and hind limb Q were again obtained. This process was repeated until cardiovascular collapse occurred. The hind limb was then injected with india ink, the animal killed, and the stained muscle dissected free and weighed.

In experiment 2 , four additional animals were exposed to both stagnant hypoxia and DNP. DNP increases $\mathrm{O}_{2}$ demand by uncoupling oxidative phosphorylation. As in experiment 1 , measurements were obtained after stepwise inflation of the atrial balloon. When hind limb Q decreased to about $25 \%$ of baseline (just before cardiovascular collapse), lambs received $6 \mathrm{mg} / \mathrm{kg}$ of DNP dissolved in sodium bicarbonate. In each case, administration of DNP increased hind limb blood flow approximately 2fold. Balloon inflation was then adjusted to produce a range of flows similar to that obtained before the administration of DNP. We were, however, unable to regain baseline flow in two lambs, most likely a result of myocardial injury from previous balloon inflation. The hind limb was then injected with ink and the animal killed, as described above.

Calculations and statistical analysis. Because the Co-Oximeter is unable to measure the $\mathrm{O}_{2}$ saturation of sheep blood, and because the presence of fetal $\mathrm{Hb}$ may result in fictitious elevations in carboxyhemoglobin concentration $(\% \mathrm{HbCO})$ as determined by the Co-Oximeter (3), the Co-Oximeter was calibrated before the study with a Lex- $\mathrm{O}_{2}$-Con- $\mathrm{K} \mathrm{O}_{2}$-sensitive cell (Hospex Fiberoptics, Waltham, MA). Assuming the Co-Oximeter-derived [Hb]
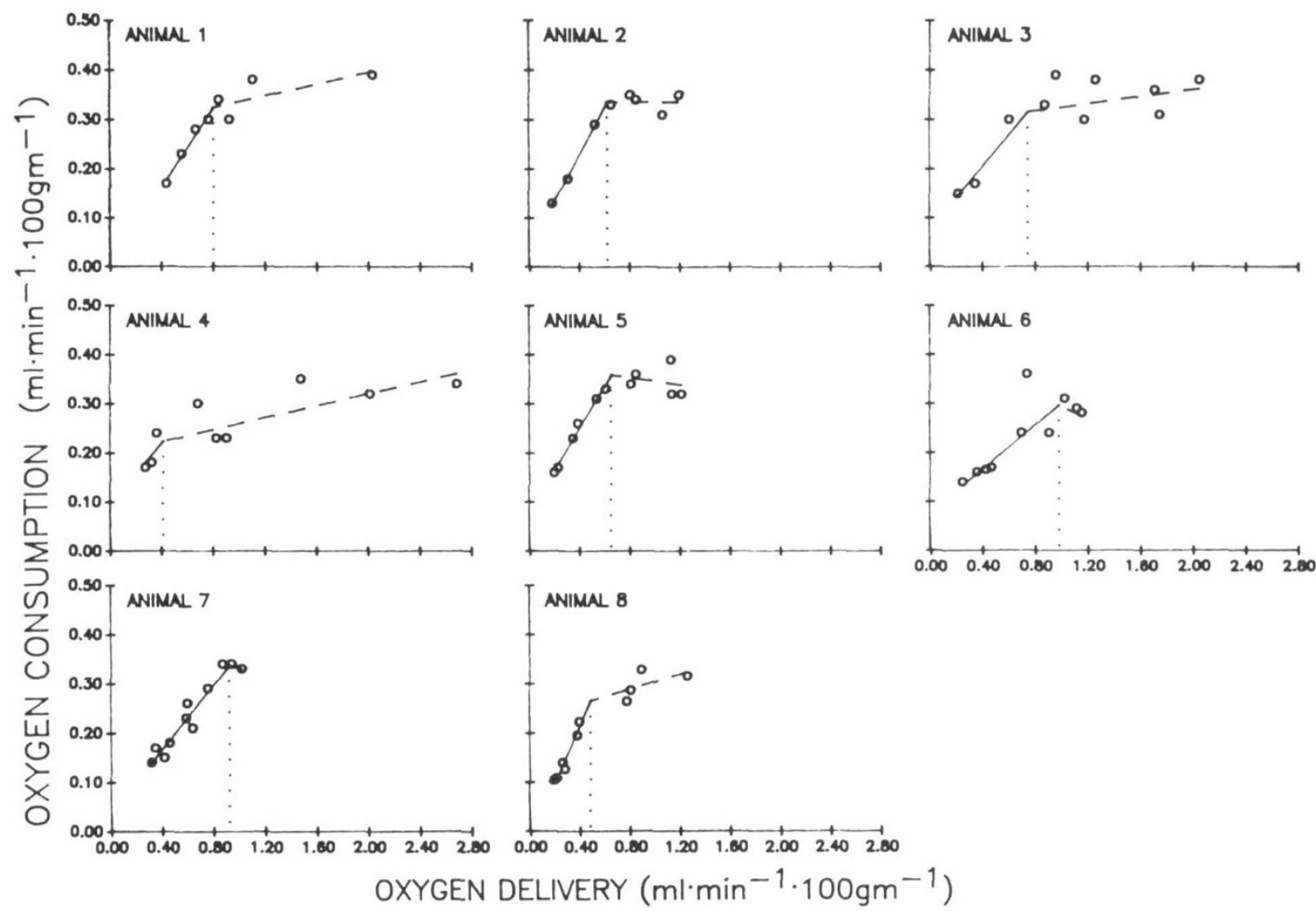

Fig. 1. Individual plots of $\mathrm{DO}_{2}$ vs $\dot{\mathrm{V}}_{2}$, experiment 1 . Individual critical levels of $\mathrm{DO}_{2}$ are shown by $(\cdots)$ ). In six of eight animals (numbers $1-5$ and 8 ), $\dot{\mathrm{V}}_{2}$ was well maintained despite reductions in $\mathrm{DO}_{2}$. 
Table 2. Comparison of baseline group mean data with that obtained at critical $\mathrm{DO}_{2}$ and at lowest flow rate $(n=6$, mean $\pm S D) *$

\begin{tabular}{lccc}
\hline & Baseline & Critical & Lowest Q \\
\hline Femoral artery Q $\left(\mathrm{mL} \cdot \mathrm{min}^{-1} \cdot 100 \mathrm{~g}^{-1}\right)$ & $12.30 \pm 3.9 \dagger$ & $4.80 \pm 1.90$ & $1.80 \pm 0.10$ \\
Hind limb $\mathrm{DO}_{2}\left(\mathrm{~mL} \cdot \mathrm{min}^{-1} \cdot 100 \mathrm{~g}^{-1}\right)$ & $1.73 \pm 0.61 \dagger$ & $0.61 \pm 0.20$ & $0.24 \pm 0.10$ \\
Hind limb $\mathrm{VO}_{2}\left(\mathrm{~mL} \cdot \mathrm{min}^{-1} \cdot 100 \mathrm{~g}^{-1}\right)$ & $0.35 \pm 0.03 \ddagger$ & $0.30 \pm 0.05 \S$ & $0.15 \pm 0.03$ \\
$\mathrm{O}_{2}$ ext & $0.22 \pm 0.06 \dagger$ & $0.51 \pm 0.11$ & $0.64 \pm 0.15$ \\
$\mathrm{pH}_{3}$ & $7.46 \pm 0.07 \dagger$ & $7.34 \pm 0.05 \S$ & $7.18 \pm 0.02$ \\
\hline
\end{tabular}

$*$ Values are mean $\pm \mathrm{SD} . \mathrm{O}_{2}$ ext, $\mathrm{O}_{2}$ extraction ratio.

$\dagger$ Different from critical and lowest values, $p<0.01$.

$\ddagger$ Different from critical and lowest values, $p<0.05$.

$\S$ Different from baseline and lowest values, $p<0.05$.

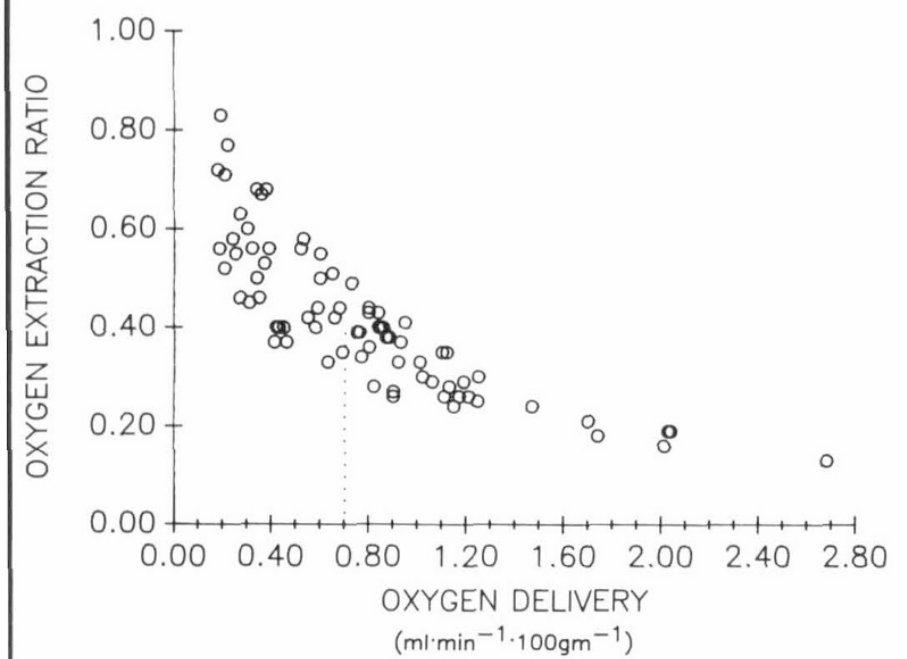

Fig. 2. Relationship between $\mathrm{DO}_{2}$ and $\mathrm{O}_{2}$ extraction ratio, all animals, experiment 1 . Below the mean critical level of $\mathrm{DO}_{2}(\cdots), \mathrm{O}_{2}$ extraction continued to increase.

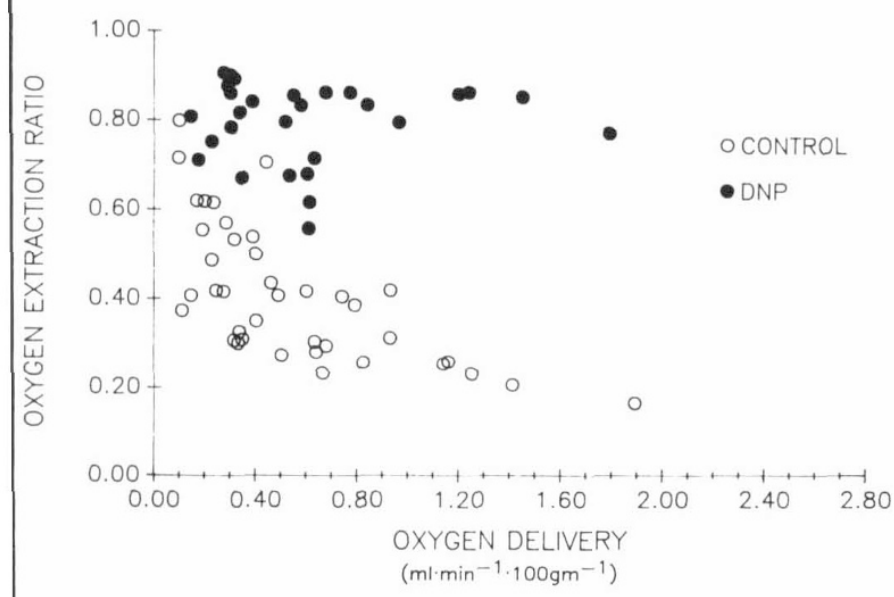

Fig. 3. Relationship between $\mathrm{DO}_{2}$ and $\mathrm{O}_{2}$ extraction ratio, experiment 2. Administration of DNP increased $\mathrm{O}_{2}$ extraction throughout the range of $\mathrm{DO}_{2}$ studied.

to be correct, we determined the relationship between $\mathrm{O}_{2}$ content as measured by the Lex- $\mathrm{O}_{2}-\mathrm{Con}-\mathrm{K}$ and $\mathrm{O}_{2}$ content as calculated from blood gas and Co-Oximeter measurements to be best described by the equation:

$\mathrm{O}_{2}$ content $_{\text {Lex-O2-Con-K }}(\mathrm{mL} / \mathrm{dL})=1.36[\mathrm{Hb}]_{\text {Co-Oximeter }}$

$\times\left(\% \mathrm{HbO}_{2 \text { Co-Oximeter }}+0.85 \times \% \mathrm{HbCO}_{\text {Co-Oximeter }}\right)+0.003 \mathrm{PO}_{2}$

where $\% \mathrm{HbO}_{2}$ is oxyhemoglobin concentration. $\mathrm{DO}_{2}$ was calcuated by multiplying hind limb Q by $\mathrm{CaO}_{2} . \mathrm{V}_{2}$ was calculated with the Fick equation. $\mathrm{O}_{2}$ extraction ratio was calculated by dividing $\mathrm{C}_{\mathrm{a}-\mathrm{v}} \mathrm{O}_{2}$ by $\mathrm{CaO}_{2} . \mathrm{P}_{50}$ was calculated for individual animals py fitting venous $\mathrm{O}_{2}$ tension and saturation (sat) to the coordihates suggested by $\mathrm{Hill}(4)$, i.e. $\log \mathrm{Po}_{2}$ versus $\log$ (sat/1 - sat).
By use of the linear regression equations thus obtained, $\mathrm{P}_{50}$ was calculated by setting $\log$ (sat/1-sat) equal to 0 .

All Q, $\mathrm{DO}_{2}$, and $\mathrm{VO}_{2}$ data were reported per $100 \mathrm{~g}$ of muscle. Group mean data were described as the mean $\pm \mathrm{SD}$. Individual $\mathrm{DO}_{2}$ crit, defined as the level of $\mathrm{DO}_{2}$ below which $\dot{\mathrm{V}}_{\mathrm{O}_{2}}$ became dependent on $\mathrm{O}_{2}$ supply, were identified at the intersection of the two regression lines maximizing the ratio of the regression sum of squares to the residual sum of squares (least sum of squares technique). Regression analysis was modified to minimize the perpendicular distance between each point and the regression line. The lines selected were chosen from all possible combinations of points grouped to construct two independent regression lines $(5,6)$. ANOVA was used to compare baseline Q, $\mathrm{DO}_{2}, \dot{\mathrm{V}}_{2}, \mathrm{O}_{2}$ extraction, and $\mathrm{pH}_{\mathrm{a}}$ values with those obtained at $\mathrm{DO}_{2}$ crit and at the lowest level of Q. Newman-Keuls' multiple range test was used to pinpoint differences identified by ANOVA (7). Single sample, paired, and unpaired $t$ tests were used where appropriate.

\section{RESULTS}

Experiment 1. Baseline measurements (Table 1). Mean baseline $\mathrm{Q}$ was $11.3 \pm 3.8 \mathrm{~mL} \cdot \mathrm{min}^{-1} \cdot 100 \mathrm{~g}^{-1}$, slightly greater than that found in the canine hind limb $(8-10)$. The mean $P_{50}$ of 3.9 $\pm 0.5 \mathrm{kPa}$ was typical of lambs of this age, and substantially less than the adult value of $5.6 \mathrm{kPa}(11)$. Although $\mathrm{pH}_{\mathrm{a}}$ was slightly elevated, these data suggest a preponderance of fetal $\mathrm{Hb}$.

Effects of stagnant hypoxia. Individual plots of hind limb $\mathrm{DO}_{2}$ versus $\dot{\mathrm{V}}_{2}$ are shown in Figure 1 . Mean $\mathrm{DO}_{2}$ crit, below which $\dot{\mathrm{V}}_{2}$ was supply-dependent, was $0.70 \pm 0.20 \mathrm{~mL} \cdot \min ^{-1} \cdot 100 \mathrm{~g}^{-1}$. The mean slope and $\dot{\mathrm{V}}_{2}$-intercept representing those data below $\mathrm{DO}_{2}$ crit were $0.38 \pm 0.11$ and $0.05 \pm 0.04 \mathrm{~mL} \cdot \mathrm{min}^{-1} \cdot 100 \mathrm{~g}^{-1}$, respectively. This $\mathrm{y}$-intercept is significantly greater than $0(p<$ 0.01 , single sample $t$ test), demonstrating that $\mathrm{O}_{2}$ extraction continued to increase below $\mathrm{DO}_{2}$ crit.

In six of eight lambs, hind limb $\dot{\mathrm{V}}_{2}$ was clearly independent of $\mathrm{DO}_{2}$ until a critically low level was reached (Fig. 1). Group mean data for these animals demonstrate that $\dot{\mathrm{V}}_{2}$ was not flowlimited (Table 2). As $\mathrm{DO}_{2}$ decreased from baseline to critical levels $\left(1.73 \pm 0.61\right.$ to $0.61 \pm 0.20 \mathrm{~mL} \cdot \mathrm{min}^{-1} \cdot 100 \mathrm{~g}^{-1}, p<0.01$, ANOVA), hind limb $\dot{\mathrm{V}}_{2}$ decreased only slightly $(0.35 \pm 0.03$ to $\left.0.30 \pm 0.05 \mathrm{~mL} \cdot \mathrm{min}^{-1} \cdot 100 \mathrm{~g}^{-1}, p<0.05\right)$ and $\mathrm{O}_{2}$ extraction ratio increased $(0.22 \pm 0.06$ to $0.51 \pm 0.11, p<0.01)$. Although $\mathrm{O}_{2}$ extraction ratio continued to increase below $\mathrm{DO}_{2}$ crit (Fig. 2), it appeared submaximal, reaching only $0.64 \pm 0.15$ at the lowest level of Q. There was a modest reduction in $\mathrm{pH}_{\mathrm{a}}$ (baseline, 7.46 $\pm 0.07 ;$ at $\mathrm{Do}_{2}$ crit, $\left.7.34 \pm 0.05, p<0.01\right)$.

In two lambs (animals 6 and 7), there was only a small plateau during which $\dot{\mathrm{V}}_{2}$ was independent of supply. $\dot{\mathrm{V}}_{2}$ may therefore have been supply-dependent in these animals.

Experiment 2. Despite balloon inflation, hind limb Q and $\mathrm{DO}_{2}$ increased immediately after DNP administration (Q before DNP, $1.8 \pm 1.3 \mathrm{~mL} \cdot \mathrm{min}^{-1} \cdot 100 \mathrm{~g}^{-1}$; after DNP, $3.3 \pm 1.8 \mathrm{~mL} \cdot \mathrm{min}^{-1}$. $100 \mathrm{~g}^{-1}, p<0.05$, paired $t$ test; $\mathrm{DO}_{2}$ before DNP, $0.22 \pm 0.13$ $\mathrm{mL} \cdot \mathrm{min}^{-1} \cdot 100 \mathrm{~g}^{-1}$; after DNP, $0.40 \pm 0.02 \mathrm{~mL} \cdot \mathrm{min}^{-1} \cdot 100 \mathrm{~g}^{-1}$, $p<0.05$ ).

DNP increased $\mathrm{O}_{2}$ extraction and $\dot{\mathrm{V}}_{2}$ throughout the range 
Table 3. Effects of DNP on $\mathrm{O}_{2}$ extraction, $\mathrm{pH}_{a}$, and $\mathrm{P}_{50}{ }^{*}$

\begin{tabular}{lcc}
\hline & Control & DNP \\
\hline $\mathrm{O}_{2}$ ext below hind limb $\mathrm{DO}_{2}$ crit & $0.48 \pm 0.15(n=24)$ & $0.79 \pm 0.10(n=18) \dagger$ \\
$\mathrm{O}_{2}$ ext at lowest femoral artery Q & $0.64 \pm 0.18(n=4)$ & $0.80 \pm 0.08(n=4)$ \\
$\mathrm{pH}_{\mathrm{a}}$ below hind limb $\mathrm{DO}_{2}$ crit & $7.24 \pm 0.11(n=24)$ & $7.10 \pm 0.16(n=18) \dagger$ \\
$\mathrm{pH}_{\mathrm{a}}$ at lowest level of femoral artery Q & $7.21 \pm 0.06(n=4)$ & $7.04 \pm 0.23(n=4)$ \\
$\mathrm{P}_{50}(\mathrm{kPa})$ & $4.4 \pm 0.50(n=4)$ & $4.5 \pm 0.50(n=4)$ \\
\hline
\end{tabular}

* Values are mean $\pm \mathrm{SD} . \mathrm{O}_{2}$ ext, $\mathrm{O}_{2}$ extraction ratio.

$\dagger$ Different from control, $p<0.01$.

of $\mathrm{DO}_{2}$ studied (Fig. 3, Table 3). Below $0.61 \mathrm{~mL} \cdot \mathrm{min}^{-1} \cdot 100 \mathrm{~g}^{-1}$ (mean $\mathrm{DO}_{2}$ crit from experiment 1 ), DNP increased $\mathrm{O}_{2}$ extraction during stagnant hypoxia by $65 \%$ [control, $0.48 \pm 0.15(n=24)$; DNP, $0.79 \pm 0.10(n=18) ; p<0.001$, unpaired $t$ test $]$. DNP increased $\mathrm{O}_{2}$ extraction at the lowest level of $\mathrm{Q}$ by $25 \%$ (control, $0.64 \pm 0.18$; DNP, $0.80 \pm 0.08$, an increase exceeding that found in the canine hind limb during hypoxic hypoxia (10).

Addition of DNP significantly reduced mean $\mathrm{pH}_{\mathrm{a}}$ below $\operatorname{DO}_{2}$ crit $(7.24 \pm 0.11$ to $7.10 \pm 0.16, p<0.001)$. Mean $\mathrm{P}_{50}$ was unchanged, however, suggesting that improved $\mathrm{O}_{2}$ extraction was not related to a rightward shift in the oxyhemoglobin dissociation curve.

\section{DISCUSSION}

In experiment 1 , hind limb $\dot{\mathrm{V}}_{\mathrm{O}_{2}}$ was clearly independent of $\mathrm{DO}_{2}$ in six of eight animals. In these lambs, reductions in hind limb Q failed to substantially decrease hind limb $\dot{\mathrm{V}}_{2}$, suggesting that $\mathrm{V}_{2}$ was not flow-limited. Qualitatively similar results have been found in the canine hind limb; however, the level of $\mathrm{O}_{2}$ extraction in 7- to 18-d-old lambs was less than that previously observed in the mature $\operatorname{dog}(5,9,12,13)$ : The mean critical $\mathrm{O}_{2}$ extraction ratio of 0.51 in the lamb hind limb compares unfavorably with that obtained in the canine hind limb by Samsel $e t$ al. (5) (critical $\mathrm{O}_{2}$ extraction ratio, 0.67). In addition, the mean $\mathrm{O}_{2}$ extraction ratio at the lowest level of blood flow $(0.64)$ was considerably less than that found in the canine hind limb by Stainsby and Otis (13) (0.75), Duran and Renkin (12) (0.80), and Cain and Chapler (9) (0.80). Although we have not repeated these experiments in mature sheep, the comparisons presented above and the high level of $\mathrm{O}_{2}$ extraction in experiment 2 strongly suggest that $\mathrm{O}_{2}$ extraction during extreme hypoxia was submaximal in the skeletal muscle of young lambs.

If submaximal $\mathrm{O}_{2}$ extraction was related to a defect in peripheral $\mathrm{O}_{2}$ use, increments in $\mathrm{O}_{2}$ demand might not increase $\mathrm{O}_{2}$ extraction. Such defects might include a smaller number of recruitable capillaries or an immaturity of mechanisms acting to match local $\mathrm{O}_{2}$ supply and demand. (We know of no data describing such developmental differences.) Tissue $\mathrm{O}_{2}$ extraction might also be limited by the increased affinity of fetal $\mathrm{Hb}$ for $\mathrm{O}_{2}$ (14). If, alternatively, $\mathrm{O}_{2}$ extraction in lamb skeletal muscle was reduced secondary to suppression of $\dot{\mathrm{V}}_{2}$, increments in $\mathrm{O}_{2}$ demand should increase $\mathrm{O}_{2}$ extraction. In experiment 2, DNP significantly increased $\mathrm{O}_{2}$ extraction during extreme hypoxia, suggesting that reduced $\mathrm{O}_{2}$ extraction was related to the suppression of $\mathrm{O}_{2}$-consuming processes, not defective peripheral $\mathrm{O}_{2}$ use. DNP increased mean hind limb $\mathrm{O}_{2}$ extraction at the lowest level of $\mathrm{Q}$ to 0.80 , a value comparable to that obtained in mature dogs exposed to DNP (10). We therefore speculate that when $\mathrm{O}_{2}$ demand is accelerated (as with DNP or exercise), the capacity of immature lamb skeletal muscle to extract $\mathrm{O}_{2}$ during hypoxia is similar to that of mature animals.

Our data are consistent with those of Sidi et al. (1), who found that total-body $\mathrm{O}_{2}$ extraction during extreme hypoxia was significantly less in 1-wk-old lambs than older (3-7 wk) animals. Because of the lack of acidosis with hypoxia and minimal increase in $\dot{\mathrm{V}}_{2}$ on recovery, Sidi et al. hypothesized that reduced $\mathrm{O}_{2}$ extraction was secondary to suppression of growth-related
$\dot{\mathrm{V}}_{2}$. Arguing that blood flow at the tissue level is directly related to $\mathrm{O}_{2}$ demand, Sidi et al. further hypothesized that reductions in growth-related $\dot{\mathrm{V}}_{2}$ occurred in muscle, bone, kidney, and skin, tissues to which $\mathrm{DO}_{2}$ had decreased during hypoxia. Similarly, Fahey and Lister (15) found that 2-wk-old lambs had smaller increases in $\dot{\mathrm{V}}_{2}$ after stagnant hypoxia than 8-wk-old lambs, suggesting a reduction in nonessential metabolism during hypoxia. Because as much as $30-35 \%$ of basal metabolic rate in the newborn lamb may be devoted to growth (1), reduction of growth-related $\dot{\mathrm{V}}_{2}$ seems a most adaptive and likely response to hypoxemia. Transient cessation of more fundamental $\mathrm{O}_{2}$-consuming processes (such as ion transport) may also be possible, however (10).

In two lambs, hind limb $\dot{V}_{\mathrm{O}_{2}}$ appeared to be dependent on $\mathrm{DO}_{2}$. It is possible that autoregulatory response of the skeletal muscle capillary bed to reduced $\mathrm{DO}_{2}$ may have been limited in these animals. Alternatively, a plateau in which $\mathrm{V}_{2}$ was independent of $\mathrm{DO}_{2}$ might have been obtained had initial flow rates been higher. Femoral artery flow in these animals may have been limited by such factors as anesthetic depression of $\mathrm{O}_{2}$ demand, or partial arterial or venous obstruction.

To avoid the myocardial depression and reduced venous return associated with barbiturates, we chose ketamine to anesthetize our experimental animals. The cardiovascular effects of ketamine are primarily related to CNS stimulation, and consist of peripheral vasoconstriction and increased heart rate (16). Vasoconstrictor tone has been shown to promote $\mathrm{O}_{2}$ extraction (17), suggesting that the relatively low level of $\mathrm{O}_{2}$ extraction observed in experiment 1 was not an artifact of ketamine anesthesia.

Determination of a critical level of $\mathrm{DO}_{2}$ assumes that $\mathrm{O}_{2}$ extraction below $\mathrm{DO}_{2}$ crit is maximal; further reductions in $\mathrm{DO}_{2}$ must then result in proportional reductions on $\dot{V}_{2}$. This model, although useful in assessing tissue $\mathrm{O}_{2}$ extraction, may be an oversimplification, however. In our study, $\mathrm{O}_{2}$ extraction increased even after $\mathrm{DO}_{2}$ crit was reached (Fig. 2). Because reductions in cardiac output were induced in a sequential manner, increments in $\mathrm{O}_{2}$ extraction below $\mathrm{DO}_{2}$ crit may have resulted from more prolonged exposure to hypoxia or increasing acidosis, both of which have been shown to increase $\mathrm{O}_{2}$ extraction $(8,17)$. Alternatively, $\mathrm{O}_{2}$ extraction might have increased below $\mathrm{DO}_{2}$ crit because the time for $\mathrm{O}_{2}$ diffusion is lengthened at low flow rates. Red cell transit time in muscle capillaries is on the order of 1000 $\mathrm{ms}$, however, too slow to limit $\mathrm{O}_{2}$ extraction at rest (18).

We have shown that although the $\dot{\mathrm{V}}_{2}$ of immature lamb skeletal muscle is not flow-limited, $\mathrm{O}_{2}$ extraction during stagnant hypoxia is submaximal. The increase in $\mathrm{O}_{2}$ extraction after administration of DNP suggests that limitations in $\mathrm{O}_{2}$ extraction result from a reduction in $\mathrm{O}_{2}$-consuming metabolism during hypoxia, rather than a defect in peripheral $\mathrm{O}_{2}$ use.

Acknowledgments. The authors thank Lindy King and Jul Koleske for their assistance in preparing the manuscript.

\section{REFERENCES}

1. Sidi D, Kuipers JRG, Teitel D, Heymann MA, Rudolph AM 1983 Develop mental changes in oxygenation and circulatory responses to hypoxemia ir lambs. Am J Physiol 245:H674-H682

2. Fahey JT, Lister G 1985 A simple method for reducing cardiac output in th conscious lamb. Am J Physiol 249:H188 H192 
3. Zwart A, Buursma A, Oeseburg B, Zijlstra WG 1981 Determination of hemoglobin derivatives with the IL 282 Co-Oximeter as compared with a manual spectrophotometric five wavelength method. Clin Chem 27:19031907

4. Hill AV 1910 The possible effects of the aggregation of the molecules of hemoglobin on its dissociation curves. J Physiol (Lond) 40:iv

5. Samsel RW, Nelson DP, Sanders WM, Wood LDH, Schumacker PT 1988 Effect of endotoxin on systemic and skeletal muscle $\mathrm{O}_{2}$ extraction. J Appl Physiol 65:1377-1382

6. Willford DC, Will EP, White FC, Moores WY 1986 Decreased critical mixed venous oxygen tension and critical oxygen transport during induced hypothermia in pigs. J Clin Monit 2:155-168

7. Snedecor GW, Cochran WG 1980 Statistical Methods. Iowa State University Press, Ames, Iowa, p 235

8. Cain SM, Adams RP $1983 \mathrm{O}_{2}$ transport during two forms of stagnant hypoxia following acid and base infusions. J Appl Physiol 54:1518-1524

9. Cain SM, Chapler CK 1979 Oxygen extraction by canine hindlimb during hypoxic hypoxia. J Appl Physiol 46:1023-1028
10. King CE, Cain SM 1987 Regional $\mathrm{O}_{2}$ uptake during hypoxia and recovery in hypermetabolic dogs. J Appl Physiol 63:381-386

11. Lister G, Walter TK, Versmold HT, Dallman PR, Rudolph AM 1979 Oxygen delivery in lambs: cardiovascular and hematologic development. Am J Physiol 237:H668-H675

12. Duran WN, Renkin EM 1974 Oxygen consumption and blood flow in resting mammalian skeletal muscle. Am J Physiol 226:173-177

13. Stainsby WN, Otis AB 1964 Blood flow, blood oxygen tension, oxygen uptake, and oxygen transport in skeletal muscle. Am J Physiol 206:858-866

14. Lister G 1984 Oxygen transport in the intact hypoxic newborn lamb: acute effects of increasing $\mathrm{P}_{50}$. Pediatr Res 18:172-177

15. Fahey JT, Lister G 1987 Response to low cardiac output: developmental differences in $\mathrm{O}_{2}$ deficit and recovery in lambs. Pediatr Res 21:199A(abstr)

16. Way WL, Trevor AJ 1986 Pharmacology of intravenous nonnarcotic anesthetics. In: Miller RD (ed) Anesthesia, 2nd Ed. Churchill-Livingstone, New York, pp 815-817

17. Cain SM 1979 Effects of time and vasoconstrictor tone on $\mathrm{O}_{2}$ extraction during hypoxic hypoxia. J Appl Physiol 45:219-224

18. Sarelius IH, Duling BR 1982 Direct measurement of microvessel hematocrit, red cell flux, velocity and transit time. Am J Physiol 243:H1018-H1026 